\title{
Rozwój zagranicznych sieci handlowych w Polsce
}

\section{THE DEVELOPMENT OF FOREIGN RETAIL CHAINS IN POLAND}

W artykule podjęto się próby określenia czynników sprzyjajacych rozwojowi zagranicznych sieci handlowych na polskim rynku głównie z branży spożywczej. Przedstawiono także informacje o fuzjach i przejęciach sieci handlowych, strukture handlu detalicznego oraz perspektyw rozwoju.

Na dalszy rozwój badanych podmiotów będa miaty znaczqcy wptyw zmiany regulacji przepisów prawnych oraz decyzje władz samorzqdowych. Samorzqdy mogq wplynać na harmonijny rozwój lokalnych sieci handlowych poprzez: unikanie monopolizacji rynku lokalnego, zapewnienie zróżnicowania form handlu, racjonalne rozmieszczenie sklepów oraz pobudzanie przedsiębiorczości i ograniczenie bezrobocia na lokalnym rynku.

Słowa kluczowe: handel detaliczny, branża spożywcza, sieci handlowe.

\section{Wstęp}

W Polsce w pierwszych latach przemian ustrojowych brakowało krajowego kapitału wyspecjalizowanego w działalności handlowej. Niszę tę wypełnił kapitał zagraniczny w formie inwestycji bezpośrednich. Na polski rynek weszły zagraniczne sieci handlowe wprowadzając nowoczesne formy sklepów detalicznych wielkopowierzchniowych, takich jak: sklepy dyskontowe, supermarkety i hipermarkety oraz domy i centra handlowe. ${ }^{1}$ Formy te zostały przeniesione z rozwiniętych krajów Europy Zachodniej i Stanów Zjednoczonych.

Polska stanowiła jedyny w Europie Środkowo-Wschodniej kraj, w którym dynamika procesów internacjonalizacji handlu była szczególnie wysoka. Wynikało to między innymi ze znacznej chłonności rynku wewnętrznego, tendencji wzrostu podaży dóbr i usług na wielu rynkach branżowych oraz dużych korzyści dla inwestorów. Zagraniczne sieci handlowe zwiększały liczbę sklepów $\mathrm{z}$ roku na rok. Był to efekt

${ }^{1}$ Do sklepów wielkopowierzchniowych wg klasyfikacji GUS zalicza się:

- domy towarowe - wielodziałowe o powierzchni sprzedaży $2000 \mathrm{~m}^{2}$ i więcej, oferujące uniwersalny asortyment towarów nieżywnościowych, a często także żywnościowych, które mogą również prowadzić pomocniczą działalność gastronomiczną i usługową;

- domy handlowe - wielodziałowe (przynajmniej dwa działy branżowe) o powierzchni sal sprzedaży od $600 \mathrm{~m}^{2}$ do $1999 \mathrm{~m}^{2}$, posiadające podobny asortyment do domów towarowych;

- supermarkety - o powierzchni sprzedaży od 400 do $2499 \mathrm{~m}^{2}$ ze sprzedażą głównie samoobsługową, oferujące szeroki asortyment artykułów żywnościowych i nieżywnościowych częstego zakupu;

- hipermarkety - o powierzchni sprzedaży powyżej $2500 \mathrm{~m}^{2}$ prowadzące sprzedaż głównie w systemie samoobsługowym oferujące szeroki i pogłębiony asortyment artykułów żywnościowych i nieżywnościowych częstego zakupu, posiadające własny parking samochodowy. 
zarówno wkraczania na polski rynek nowych przedsiębiorstw zagranicznych, jak i przejmowania przez nie części lub całości krajowych firm handlowych. ${ }^{2}$

Celem rozważań jest określenie czynników sprzyjających wejściu i utrzymaniu się na polskim rynku po 1989 roku zagranicznych sieci handlowych (głównie w branży spożywczej), przedstawienie informacji o fuzjach i przejęciach sieci, struktury handlu detalicznego wg sieci oraz perspektyw rozwoju. Badania przeprowadzono na podstawie polskiej literatury oraz raportów analitycznych Instytutu Badań Rynku, Konsumpcji i Koniunktur, Profit Systemu, Głównego Urzędu Statystycznego oraz magazynu Handel. Okres badawczy obejmuje ogółem lata 1990-2014, szczegółowo lata 2010-2014.

\section{Początki rozwoju sieci handlowych w Polsce}

Zagraniczne sieci handlowe inwestowały w Polsce głównie w sklepy wielkopowierzchniowe. Pierwszy supermarket powstał w Warszawie w 1990 roku. Na przykładzie tej sieci można prześledzić zmiany właścicieli kapitału. Był to pierwotnie sklep polsko-austriackiej firmy Billa. Polska spółka Billa Polen początkowo należała do: austriackiej Euro-Billi, Polmarcu i Mitpolu (spółki S. Wiatra, A. Kuny i A. Żagla). Następnie 75\% udziałów przeszło do Euro-Billa, a pozostałe do Polmarcu. W 1996 roku koncern Rewe-Zentral AG kupił austriacką Billę i skoncentrował się na sklepach Minimal, gdyż nie mógł dojść do porozumienia z polskimi udziałowcami. W połowie 2001 roku grupa Auchan wykupiła udziały polskiej Billi. Nowi właściciele zmienili aranżacje i logo 11 sklepów Billi na Elea. Prekursorem sklepów dyskontowych na polskim rynku była sieć Globi, w 1991 roku należąca do belgijskiej firmy GIB Group, a od 2000 roku do francuskiej sieci Carrefour. Pierwszym hipermarketem działającym w Polsce był HIT należący do niemieckiej firmy Dolhe. Sieć ta rozpoczęła działalność w 1993 roku. W lipcu 2002 roku wszystkie 13 sklepów HIT zostało przejętych przez brytyjską sieć Tesco (tab. 1). ${ }^{3}$

Tabela 1. Początki działalności głównych sieci handlowych w Polsce według wybranych form sklepów

\begin{tabular}{|c|c|c|c|c|c|}
\hline Nazwa firmy & Rok & Nazwa firmy & Rok & Nazwa firmy & Rok \\
\hline \multicolumn{2}{|l|}{ Sklepy dyskontowe } & \multicolumn{2}{|l|}{ Supermarkety } & \multicolumn{2}{|l|}{ Hipermarkety } \\
\hline Globi (GIB Group/Belgia) & 1991 & Billa (Austria) & 1990 & $\begin{array}{l}\text { HIT } \\
\text { (Dohle/Niemcy) }\end{array}$ & 1993 \\
\hline REMA 1000 (Norwegia) & 1992 & IKEA (Szwecja) & 1990 & $\begin{array}{l}\text { Makro Cash \&Carry } \\
\text { (Holandia) }\end{array}$ & 1993 \\
\hline $\begin{array}{l}\text { Netto (Dansk } \\
\text { Supermarket/Dania) }\end{array}$ & 1995 & E.Leclerc (Francja) & 1992 & $\begin{array}{l}\text { Geant } \\
\text { (Casino/Francja) }\end{array}$ & 1995 \\
\hline $\begin{array}{l}\text { Plus Discount } \\
\text { (Tengelmann/Niemcy) }\end{array}$ & 1995 & $\begin{array}{l}\text { Leroy Merlin } \\
\text { (Auchan/Francja) }\end{array}$ & 1994 & $\begin{array}{l}\text { Real (Metro AGD } \\
\text { /Niemcy) }\end{array}$ & 1995 \\
\hline $\begin{array}{l}\text { Biedronka (Jeronimo } \\
\text { Martins/Portugalia) }\end{array}$ & 1997 & Tesco-Savia (Anglia) & 1995 & Auchan (Francja) & 1996 \\
\hline
\end{tabular}

\footnotetext{
${ }^{2}$ Joanna Wrzesińska, Rozwój wielkoobszarowych obiektów handlowych w Polsce [w] Zeszyty Naukowe SGGW w Warszawie, Ekonomika i Organizacja Gospodarki Żywnościowej, nr 72 (2008), str.161-170.

${ }^{3}$ Tamże, s.163.
} 


\begin{tabular}{|l|l|l|l|l|l|}
\hline Edeka (Niemcy) & $\mathbf{1 9 9 7}$ & $\begin{array}{l}\text { Leader Price } \\
\text { (Casino/Francja) }\end{array}$ & $\mathbf{2 0 0 1}$ & Castorama & $\mathbf{1 9 9 6}$ \\
\hline & & $\begin{array}{l}\text { Tesco (Wielka } \\
\text { Brytania) }\end{array}$ & $\mathbf{1 9 9 8}$ \\
\hline
\end{tabular}

Źródło: Opracowano na podstawie: Katalog Sieci Detalicznych w Polsce TRADE PRESS, http://sd.tradepress.com.pl/, data dostępu: 21.08.2006.

Wśród czynników zachęcających zagraniczny kapitał do inwestowania w Polsce w latach 90 tych, wymienia się:

- postępy we wdrażaniu reform systemowych i prywatyzacji;

- chłonność rynku wewnętrznego;

- stosunkowo tanią i dobrze wykwalifikowaną siłę roboczą;

- stabilizację polityczną;

- przewidywany wzrost gospodarczy.

Szybki rozwój zagranicznych sieci handlowych wynikał także z dużego doświadczenia w tej dziedzinie firm które posiadały nowoczesną kadrę zarządzającą.

Aby rozwijać się i umacniać swoją pozycję na rynku sieci handlowe tworzą mniejsze formaty sklepów (zmniejszając hiper na super, super na dyskont) oraz decydują się na fuzje i przejęcia. Ostatnie wielkie przejęcie w Polsce nastąiło w 2014 roku, Urząd Ochrony Konkurencji i Konsumentów wydał zgodę na przejęcie przez Auchan sieci Real. Wśród wymienionych sieci handlowych przeważają na polskim rynku firmy z Francji. (tab. 2).

Tabela 2. Fuzje i przejęcia sklepów wielkopowierzchniowych w Polsce w latach 2000-2014

\begin{tabular}{|c|c|c|c|c|c|}
\hline Rok & Sieć & $\begin{array}{l}\text { Nazwa } \\
\text { sklepu }\end{array}$ & Typ sklepu & $\begin{array}{c}\text { Liczba } \\
\text { przejętych } \\
\text { sklepów }\end{array}$ & Nowy właściciel \\
\hline 2000 & GB (Francja) & Globi & Supermarket & 26 & Carrefour (Francja) \\
\hline 2001 & Rewe (Niemcy) & Billa & Supermarket & 11 & Auchan (Francja) \\
\hline 2002 & Dohle (Niemcy) & HIT & Hipermarket & 13 & Tesco ( Wielka Brytania) \\
\hline 2002 & $\begin{array}{l}\text { Jeronimo Martins } \\
\text { (Portugalia) }\end{array}$ & Jumbo & Hipermarket & 5 & Ahold (Holandia) \\
\hline 2003 & Edeka (Niemcy) & $\begin{array}{l}\text { E-discount, } \\
\text { E-supersam }\end{array}$ & Dyskont & 45 & Rojal Markety (Polska) \\
\hline 2003 & $\begin{array}{l}\text { DRD Food } \\
\text { Emporium } \\
\text { (Norwegia) }\end{array}$ & Rema 1000 & Supermarket & 16 & $\begin{array}{l}\text { Jeronimo Martins } \\
\text { (Portugalia) }\end{array}$ \\
\hline 2003 & Ahold (Holandia) & Hypernova & Hipermarket & 2 & Carrefour (Francja) \\
\hline 2004 & Ahold (Holandia) & Hypernova & Hipermarket & 13 & $\begin{array}{c}\text { Carrefour } \\
\text { (Francja) }\end{array}$ \\
\hline 2006 & ABC (Polska) & $\mathbf{A B C}$ & Supermarket & 17 & Polomarket (Polska) \\
\hline 2006 & $\begin{array}{c}\text { Delikatesy Centrum } \\
\text { (Polska) }\end{array}$ & $\begin{array}{l}\text { Delikatesy } \\
\text { Centrum }\end{array}$ & Siec sklepów & 200 & Eurocash (Polska) \\
\hline 2006 & Geant (Francja) & $\begin{array}{l}\text { Leader } \\
\text { Price }\end{array}$ & Dyskont & 142 & Tesco (Wielka Brytania) \\
\hline 2006 & Geant (Francja) & Geant & Hipermarket & 19 & Metro/Real (Niemcy) \\
\hline 2006 & Ahold (Holandia) & $\begin{array}{c}\text { Albert, } \\
\text { Hypernova }\end{array}$ & $\begin{array}{l}\text { Supermarket } \\
\text { Hipermarket }\end{array}$ & $\begin{array}{c}183 \\
15\end{array}$ & Carrefour (Francja) \\
\hline
\end{tabular}




\begin{tabular}{|c|c|c|c|c|c|}
\hline $\mathbf{2 0 0 9}$ & Billa (Austria) & Billa & Supermarkety & 25 & E.Leclerc (Francja) \\
\hline $\mathbf{2 0 1 4}$ & $\begin{array}{c}\text { Metro/Real } \\
\text { (Niemcy) }\end{array}$ & Real & Hipermarket & 54 & Auchan ( Francja) \\
\hline
\end{tabular}

Źródło: Opracowano na podstawie: Katalog Sieci Detalicznych w Polsce TRADE PRESS,

http://sd.tradepress.com.pl/

Sieci handlowe w Polsce dzielimy ze względu na formę własności kapitału (zagraniczna lub krajowa). Sieci z kapitalem zagranicznym skupiają największe europejskie firmy takie jak:

- w grupie hiper i supermarketów: Auchan, Kaufland, TESCO, Carrefour i E.Leclerc,

- w grupie dyskontów: Biedronka, Lidl, Netto i Aldi (tab. 3).

$\mathrm{W}$ efekcie dynamicznego rozwoju zagranicznych inwestycji w handlu nastapił prawie całkowity monopol zagranicznych operatorów w segmencie hipermarketów oraz ich bardzo silna pozycja w segmencie supermarketów i sklepów dyskontowych.

Wśród operatorów sieci $\mathbf{z}$ kapitałem krajowym działających przede wszystkim na zasadzie franczyzy przeważa forma sklepów dyskontowych i supermarketów, wśród których wyróżnia się: delikatesy PSS „Społem”, Delikatesy centrum, Polomarket, Piotr i Pawel, MarcPol (tab. 3).

Dynamiczny rozwój zagranicznych sieci wymuszał procesy prywatyzacyjne, aktywizował przedsiębiorczość wśród polskich przedsiębiorców i powodował efekty naśladowcze dla krajowego kapitału w handlu.

Przykładem wzrostu przedsiębiorczości i konsolidacji wśród polskich firm było m.in. utworzenie w lutym 2000 roku przez jedenaście polskich sieci handlu detalicznego Unii Polskich Sieci Detalicznych (UPSD). W jej skład weszły: Chata Polska S.A., Lewiatan '94 S.A., Lewiatan Opole Sp. z o.o., Lewiatan Pomorze Sp. z o.o., Lewiatan Wielkopolska Sp. z o.o., Polska Sieć Handlowa Lider S.A., Polska Sieć Handlowa „Euro sklep” obecnie „Sklep Euro” Bielsko-Biała, Polska Sieć Handlowa Rabat Katowice, Rabat Pomorze S.A. Gdańsk, Sklepy Familijne S.A. Zgodnie ze statutem tej organizacji, jej celem jest reprezentowanie i ochrona wspólnych interesów członków. Ochrona interesów członków UPSD obejmuje współpracę z producentami, dystrybutorami i innymi podmiotami gospodarczymi. Ponadto UPSD realizuje swe cele poprzez monitorowanie konkurencji, wzajemną wymianę informacji co do prowadzonej działalności, organizowania i prowadzenie doradztwa, a także szkoleń dla członków Unii oraz organizowanie konferencji i sympozjów. ${ }^{4}$

\footnotetext{
4 Joanna Wrzesińska, Warunki rozwoju sklepów wielkopowierzchniowych w Polsce, Nowe trendy w dystrybucji produktów żywnościowych : determinanty i kierunki ewolucji / red. nauk. Zygmunt Waśkowski, Michał Sznajder, s. 34-45.
} 
Tabela 3. Główne sieci nowoczesnych form handlu w Polsce w 2014 r.

\begin{tabular}{|c|c|c|c|c|c|}
\hline $\begin{array}{l}\text { Nazwy sieci } \\
\text { handlowej }\end{array}$ & $\begin{array}{l}\text { Sprzedaż } \\
\text { (mln zl) }\end{array}$ & $\begin{array}{c}\text { Liczba } \\
\text { sklepów } \\
\text { (szt.) }\end{array}$ & $\begin{array}{l}\text { Powierzchnia } \\
\qquad\left(\mathrm{m}^{2}\right)\end{array}$ & $\begin{array}{c}\text { Średnia } \\
\text { powierzchnia } \\
\left(\mathrm{m}^{2}\right)\end{array}$ & $\begin{array}{c}\text { Udzial w } \\
\text { rynku } \\
(\%)\end{array}$ \\
\hline \multicolumn{6}{|c|}{ Hipermarkety } \\
\hline Auchan & 10315 & 79 & 947131 & 11989 & 4 \\
\hline Kaufland & 8310 & 185 & 464535 & 2511 & 3 \\
\hline Tesco & 6926 & 88 & 566368 & 6436 & 3 \\
\hline Carrefour & 4896 & 89 & 452120 & 5080 & 2 \\
\hline E.Leclerc & 2308 & 16 & 91424 & 5714 & 1 \\
\hline \multicolumn{6}{|c|}{ Supermarkety } \\
\hline Tesco & 4407 & 370 & 350020 & 964 & 2 \\
\hline Intermarche & 4050 & 216 & 233280 & 1080 & 2 \\
\hline Delikatesy centrum & 3970 & 965 & 226775 & 235 & 2 \\
\hline Polomarket & 3880 & 436 & 218000 & 500 & 2 \\
\hline Carrefour Market & 2176 & 129 & 118809 & 921 & 1 \\
\hline Top Market & 2430 & 479 & 143700 & 300 & 1 \\
\hline Piotr i Paweł & 2140 & 115 & 133400 & 1160 & 1 \\
\hline Stokrotka & 1990 & 256 & 163840 & 640 & 1 \\
\hline Dino & 1659 & 377 & 150800 & 400 & 1 \\
\hline Alma & 1020 & 45 & 119070 & 2646 & 0 \\
\hline Eko & 860 & 250 & 75000 & 300 & 0 \\
\hline MarcPol & 612 & 62 & 57350 & 925 & 0 \\
\hline Simply Market & 520 & 33 & 56100 & 1700 & 0 \\
\hline E.Leclerc & 504 & 28 & 40964 & 1463 & 0 \\
\hline Spar & 531 & 189 & 51597 & 273 & 0 \\
\hline \multicolumn{6}{|c|}{ Dyskonty } \\
\hline Biedronka & 35510 & 2558 & 1603866 & 627 & 15 \\
\hline Lidl & 11210 & 545 & 401120 & 736 & 5 \\
\hline Netto & 2990 & 334 & 188710 & 565 & 1 \\
\hline Aldi & 603 & 89 & 65504 & 736 & 0 \\
\hline
\end{tabular}

Źródło: Grocery retail in Poland, PMR. 


\section{Struktura handlu detalicznego w Polsce}

W okresie 2002-2012 zmienił się obraz i struktura handlu detalicznego w Polsce. Ogólna liczba sklepów zmniejszyła się, jednocześnie zwiększyła się liczba sieci handlowych i sklepów wielkopowierzchniowych (o powierzchni powyżej $400 \mathrm{~m}^{2}$ ), które wyparły z rynku małe sklepy zajmując w 2012 roku ponad 50\% całkowitej powierzchni handlowej. ${ }^{5}$

W badanym okresie udział małych sklepów na polskim rynku detalicznym produktów szybko zbywalnych spadł z 68 do 46,3\%. Natomiast ponad 10\% wzrost odnotowały supermarkety i sklepy dyskontowe. Hipermarkety charakteryzowały się niewielkim 1\%-owym wzrostem udziału co oznaczało nasycenie rynku tego typu sklepami (Wykres. 1).

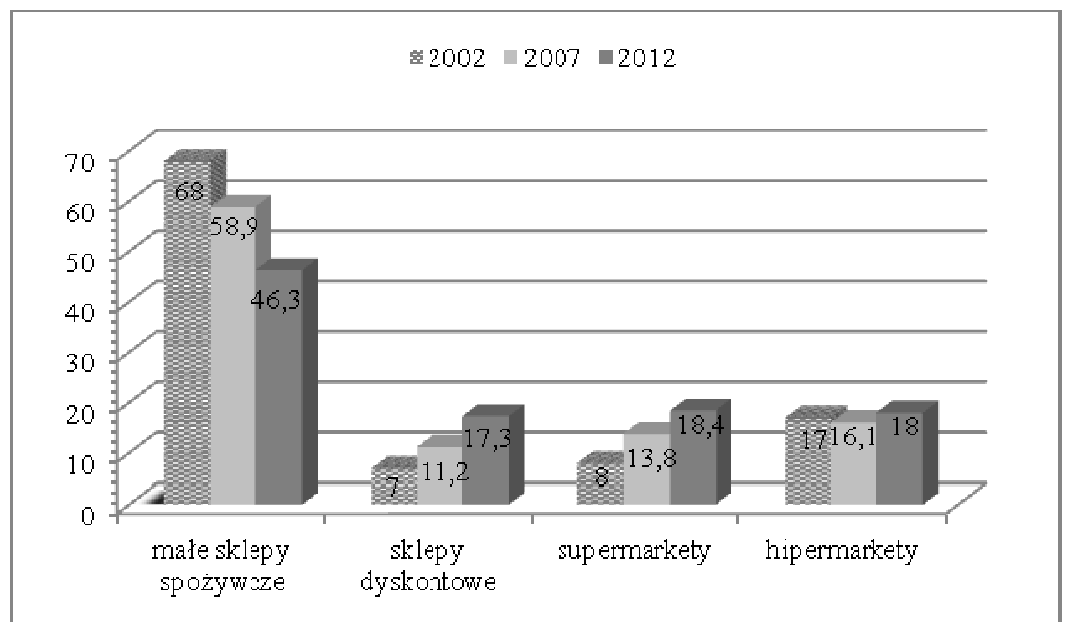

Wykres 1. Struktura handlu detalicznego FMCG w Polsce według rodzajów sklepów w latach 2002, 2007 i $2012(\mathrm{w} \%)$

Źródło: Opracowano na podstawie: Euromonitor International.

Skala nasycenia wielkopowierzchniowymi sklepami sieciowymi jest mocno zróżnicowana na poziomie województw, co odzwierciedla duże zróżnicowanie gospodarcze regionów Polski. Przykładem może być region ściany wschodniej (o niskim poziomie PKB per capita i niskiej urbanizacji) w porównaniu do centralnej Polski bardziej rozwiniętej gospodarczo i silniej zurbanizowanej. ${ }^{6}$

Najprawdopodobniej dalszy rozwój sieci handlowych wynikać będzie głównie z trendów rozwojowych kraju, w tym ze wzrostu siły nabywczej mieszkańców słabiej

\footnotetext{
5 Informacje prasowe, Handel w Polsce - prognozy na przyszłość, Warszawa, 22 maja 2014 r., http://www2.deloitte.com, data dostępu: 5.09.2016.

${ }^{6}$ Artur Tomaszewski, Prezes Zarządu DNB Bank Polska, Co dalej z handlem w Polsce? Komentarze ekspertów， www.dnb.pl/pl/komentarze-ekspertow/art16,co-dalej-z-handlem-w-polsce.html, data dostępu: 3.09.2016.
} 
rozwiniętych regionów, rozwoju urbanizacji oraz poprawy infrastruktury drogowej umożliwiającej odległe podróże po tańsze zakupy, w tym także rozwój handlu przygranicznego. Coraz większe znaczenie dla handlu nabiera ekonomia skali, więc polskie firmy, decydując o dalszym rozwoju, muszą planować strategie dopasowane do regionu na którym działają, w tym sprzedaż produktów regionalnych.

W latach 2010-2015 nastąił ponad 13\% wzrost udziału 10 największych sieci handlowych w strukturze polskiego rynku z 42,5 do 57,7\%, jednocześnie zmalał udział pozostałych sieci (handel tradycyjny i nowoczesny) z 57,5 do 42, $3 \%$ (Tab. 4).

Tabela 4. Struktura handlu spożywczego według największych sieci w Polsce w latach 2010-2015 (w \%)

\begin{tabular}{|l|l|l|l|l|l|l|}
\hline \multirow{2}{*}{ Sieci handlowe } & \multicolumn{6}{c|}{ Rok } \\
\cline { 2 - 8 } & \multicolumn{1}{|c|}{$\mathbf{2 0 1 0}$} & $\mathbf{2 0 1 1}$ & $\mathbf{2 0 1 2}$ & $\mathbf{2 0 1 3}$ & $\mathbf{2 0 1 4}$ & $\mathbf{2 0 1 5}$ \\
\hline Biedronka & 10,8 & 13 & 14,7 & 16,5 & 17 & 18,4 \\
\hline Tesco & 6,1 & 6,5 & 6,3 & 5,8 & 5,8 & 5,8 \\
\hline Lidl & 2,9 & 3,3 & 4 & 4,4 & 5,1 & 5,6 \\
\hline Kaufland & 4,7 & 5,3 & 5,2 & 5,6 & 5,5 & 5,5 \\
\hline Auchan & 3,5 & 3,3 & 3,2 & 3,1 & 3,5 & 4,6 \\
\hline ABC & 2,9 & 3,1 & 3,5 & 3,8 & 4,1 & 4,5 \\
\hline Lewiatan & 3,8 & 4 & 3,8 & 3,9 & 4,1 & 4,4 \\
\hline Carrefour/Globi & 4,6 & 4,3 & 4 & 3,6 & 4,3 & 3,4 \\
\hline Żabka/ Fresz market & 1,5 & 1,6 & 2 & 2,4 & 2,9 & 3,1 \\
\hline Intermarche & 1,6 & 1,9 & 2 & 2,1 & 2,1 & 2,5 \\
\hline $\begin{array}{l}\text { Skumulowany udział w } \\
\text { rynku TOP 10 }\end{array}$ & 42,5 & 46,2 & 48,6 & 51,1 & 54,3 & 57,7 \\
\hline $\begin{array}{l}\text { Udział pozostałych sieci } \\
\text { (handel tradycyjny i } \\
\text { nowoczesny) }\end{array}$ & 57,5 & 53,8 & 51,4 & 48,9 & 45,7 & 42,3 \\
\hline Źr & & & & & & \\
\hline
\end{tabular}

Źródło: Dziesięć sieci zdominowało rynek handlowy w Polsce, www.wiadomoscihandlowe, dostęp 10.10.2016.

\section{Czynniki wpływające na rozwój sieci handlowych}

Wśród czynników wpływających na rozwój detalicznych sieci handlowych należy wymienić następujące trendy konsumenckie:

1. nacisk na wygodę i łatwość zakupów,

2. poszukiwanie "czegoś autentycznego, swojskiego" - zwiększający się popyt zgłaszany na produkty lokalne, ${ }^{7}$

3. zdrowie i jakość produktów (np. niska zawartość cukru, produkty ekologiczne),

4. smart shoping (poszukiwanie niższej ceny przy większej jakości, np. promocji),

\footnotetext{
7 Jolanta Tkaczyk, Trendy konsumenckie i ich implikacje marketingowe, Handel wewnętrzny, Konsumpcja i konsument -nowe trendy, maj-czerwiec 2012, s.126-134.
} 
5. starzenie się społeczeństwa,

6. zmiana modelu rodziny (zwiększanie się liczby jednoosobowych gospodarstw domowych),

7. internetyzacja życia codziennego w tym zakupów (zwiększająca się popularność zakupów przez Internet),

8. mobilność (urządzenia i aplikacje mobilne, zdobywające szybkie informacje i ułatwiające podejmowanie decyzji zakupowych).

$\mathrm{Na}$ rozwój sieci handlowych mają także wpływ czynniki, które powodują obniżenie zyskowności firm. Zalicza się do nich:

1. presje cenowe ze strony konkurentów,

2. koszty najmu/stawki czynszów,

3. koszty pracy,

4. presje cenowe ze strony konsumenta,

6. trendy regulacyjne:

- regulacje podatkowe,

- regulacje z dostawcami,

- regulacje antykoncentracyjne/antymonopolowe,

- prawo pracy,

- zasady oznakowania produktów,

- regulacje dotyczące wyrobów akcyzowych,

- prawa konsumentów.

Największe przychody wśród głównych sieci handlowych na polskim rynku w latach 2007-2012 osiagnęła grupa Jeronimo Martins Dystrybucja S.A do której należy sieć Biedronka (wykres 2).

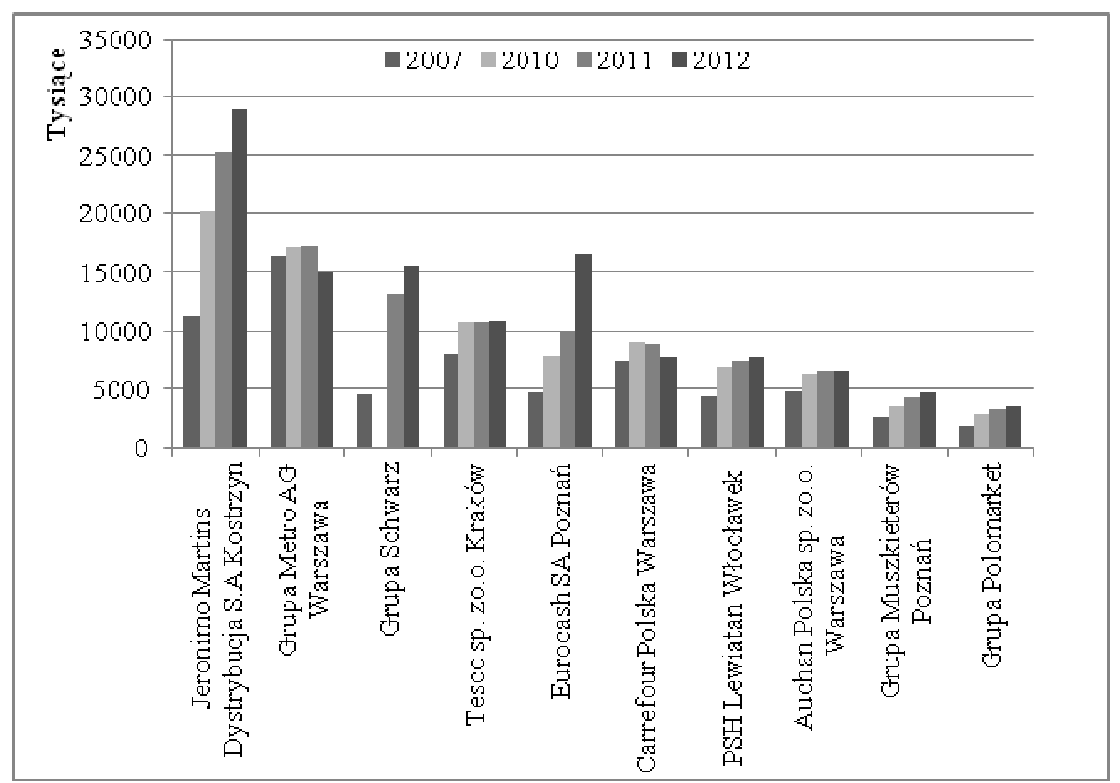

Wykres 2. Przychody ze sprzedaży największych sieci handlowych w Polsce w latach 2007-2012 Źródło: opracowano na podstawie: Piotr Chechelski, Wpływ korporacji handlowych na polski rynek spożywczy, Zagadnienia Ekonomiki Rolnej Zeszyt: 2 (343), s. 5 . 


\section{Regulacje prawne w sferze handlu}

W Polsce nie ma uregulowanych przepisów prawa odnośnie funkcjonowania sieci handlowych. Do powstałych przepisów prawa zalicza się:

> Ustawę o planowaniu zagospodarowania przestrzennego z 2003 r., która wprowadziła regulacje odnośnie lokalizacji obiektów powyżej $2000 \mathrm{~m}^{2}$ powierzchni sprzedażowej; ${ }^{8}$

> W 2015 r. uchwalono nowelizację w myśl której będą obowiązkowe konsultacje z mieszkańcami na etapie prac planistycznych dla inwestycji przed przygotowaniem projektu studium i planu miejscowego, ${ }^{9}$

> Ustawę z 2007 r. o tworzeniu i działaniu wielkopowierzchniowych obiektów handlowych - która została uchylona w 2008 r.; ${ }^{10}$

> Ustawę z 2016 r. o podatku od sprzedaży detalicznej. Wprowadza dwie stawki podatku od obrotów miesięcznych w handlu detalicznym: 0,8 \% od przychodu między 17 - 170 mln zł i 1,4 \% od przychodu powyżej 170 mln zł. Kwota wolna od podatku w skali roku ma wynosić $204 \mathrm{mln} \mathrm{zł}^{11} \quad$ Podobne rozwiązanie obowiązuje na Węgrzech, gdzie funkcjonuje ryczałtowy podatek od sklepów w wysokości $0,01 \%$ wartości sprzedaży netto. We Francji wprowadzono opłatę wymierzaną od rocznych obrotów na $1 \mathrm{~m}^{2}$ powierzchni lokalu dotyczącą największych sieci handlowych o powierzchni ponad $400 \mathrm{~m}^{2}$ i obrotach powyżej 460 tys. Euro rocznie. W Hiszpanii funkcjonuje podatek regionalny naliczany od powierzchni lokalu przekraczającej 2,5 tys. $\mathrm{m}^{2}{ }^{12}$

Komisja Europejska (KE) w połowie września 2016 r. wydała nakaz zobowiązujący polskie władze do zawieszenia stosowania ww. podatku. Najwięcej wątpliwości wg KE wzbudzają progresywne stawki oparte na wielkości przychodów oraz wysoka kwota wolna od podatku, które w praktyce oznaczać mogą, iż przedsiębiorstwa o niskich przychodach uzyskają selektywną przewage nad swoimi konkurentami, z naruszeniem unijnych zasad pomocy państwa. ${ }^{13}$

Zdaniem ekspertów z Polskiej Izby Handlu celem wprowadzenia nowego podatku od sprzedaży detalicznej powinno być ${ }^{14}$ :

- Uzyskanie założonego poziomu dochodów budżetu państwa;

- Wyrównanie szans między wielkimi sieciami i sieciami dyskontów, a mniejszymi przedsiębiorcami;

\footnotetext{
${ }^{8}$ Dz.U. 2003 nr 80 poz. 717, Ustawa z dnia 27 marca 2003 r. o planowaniu i zagospodarowaniu przestrzennym.

Dz.U. 2015 poz. 1713, Ustawa z dnia 25 września 2015 r. o zmianie ustawy o planowaniu i zagospodarowaniu przestrzennym.

10 Dz.U. $2007 \mathrm{nr}$ 127, poz.880, Ustawa $\mathrm{z}$ dnia 11 maja 2007 r. o tworzeniu i działaniu wielkopowierzchniowych obiektów handlowych.

${ }^{11}$ Dz.U. 2016 poz. 1155 , Ustawa z dnia 6 lipca 2016 r. o podatku od sprzedaży detalicznej.

${ }^{12}$ Unia Europejska zablokowała podatek od handlu, http://wgospodarce.pl/informacje/29467, data dostępu: 21.09.2016.

${ }^{13}$ Ministerstwo Finansów chce zawieszenia podatku handlowego do 2018 r.!, www.wiadomoscihandlowe.pl, data dostępu: 14.10.2016.

${ }^{14}$ Polska Izba Handlu PIH, Jak podatek od dyskontów i hipermarketów może wzmocnić właścicieli polskich sklepów?, 5.01.2016.
} 
- Powstrzymanie tempa dalszej ekspansji dyskontów i wielkich sieci zagranicznych;

- Doprowadzenie do efektywnego opodatkowania sieci wielkopowierzchniowych, które unikają pełnego opodatkowania w Polsce transferując część zysków za granicę;

- Wsparcie rodzimych producentów żywności, którzy w dużej mierze sprzedają swoje produkty w lokalnych sklepach małych i średnich przedsiębiorstw.

$\mathrm{Na}$ początku września 2016 Komitet Inicjatywy Ustawodawczej (w skład którego wchodzi NSZZ "Solidarność" oraz inne organizacje) złożył w Sejmie społeczny projekt ustawy ograniczający handel w niedzielę i święta.

Ustawowe ograniczenie handlu w niedziele nie jest ewenementem w skali Unii Europejskiej. Ograniczenia handlu w niedziele funkcjonują w różnym kształcie w większości krajów zachodniej Europy m.in w Austrii, Niemczech, Francji, Szwajcarii, Wielkiej Brytanii, Belgii czy Danii.

\section{Perspektywy rozwoju handlu}

Polski handel wewnętrzny z uwagi na duży stopień nasycenia rynku i coraz bardziej zaostrzającej się konkurencji będzie zmieniał kierunki rozwoju. Do najważniejszych zmian zalicza się:

1. Multiformatowość, czyli dywersyfikacja formatów handlu przez przedsiębiorstwa handlowe - łączenie $\mathrm{w}$ jednej firmie handlowej różnych konceptów sklepów, zróżnicowanych pod względem powierzchni i dostosowanych do potencjału lokalnych rynków; ${ }^{15}$

2. Multikanałowość - tworzenie synergii między sprzedażą online i offline, dodatkowa sprzedaż online z dostawą do domu, rozwój e-handlu;

3. Powstawanie mniejszych obiektów, lokalizowanych blisko miejsc zamieszkania konsumentów;

4. Konsolidacja i kooperacja rodzimych placówek handlowych (rozwój franczyzy);

5. Zagospodarowanie nisz rynkowych poprzez powstanie ulic handlowych na których funkcjonować będą m.in. sklepy łączące różne koncepty asortymentowo-usługowe np. kawiarni i convenience store;

6. Rozwój supermarketów z szeroką ofertą artykułów delikatesowych (np.: Piotr i Paweł);

7. Rozszerzanie oferty producentów lokalnych;

8. Personalizacja oferty na kilku poziomach, np. asortymentu, komunikacji, cen, sposobu i miejsca zakupu.

9. Wpływ czynników pozaekonomicznych na rozwój sieci handlowych poprzez:

○ media społecznościowe,

○ poprawę wizerunku firmy,

${ }^{15}$ U. Kłosiewicz-Górecka, Prezentacja raportu o handlu - stare i nowe dylematy rozwoju handlu w Polsce, Instytut Badań Rynku, Konsumpcji i Koniunktur, Polska Organizacja Handlu i Dystrybucji, konferencja z 18.01.2016. 
wzrost odpowiedzialności społecznej - priorytety CSR,
o poprawę relacji z klientami biznesowymi.

\section{Podsumowanie}

W Polsce sieci handlowe pojawiły w latach 90 i przechodziły różne fazy rozwoju. W przeważającym stopniu należały do kapitału zagranicznego, jednakże $\mathrm{z}$ czasem rozwinęły się także i umocniły polskie firmy, głównie w formie franczyzy.

Po czasie agresywnej konkurencji, walki cenowej i intensywnej pracy nad ofertą, polski rynek handlu detalicznego staje się coraz bardziej nasycony i charakteryzuje go zaostrzająca się walka konkurencyjna.

Sieci handlowe wobec zmieniającej się sytuacji rynkowej powinny podjąć indywidualne strategie rozwoju kompatybilne $\mathrm{z}$ wymienionymi $\mathrm{w}$ artykule kierunkami zmian w handlu wewnętrznym.

Dużą role w rozwoju handlu odegrają zmiany regulacji przepisów prawnych oraz decyzje władz samorządowych. Samorządy mogą wpłynąć na harmonijny rozwój lokalnych sieci handlowych poprzez: unikanie monopolizacji rynku lokalnego, zapewnienie zróżnicowania form handlu, racjonalne rozmieszczenie sklepów oraz pobudzanie przedsiębiorczości i ograniczenie bezrobocia na lokalnym rynku.

\section{Literatura}

1. Piotr Chechelski, Wpływ korporacji handlowych na polski rynek spożywczy, Zagadnienia Ekonomiki Rolnej Zeszyt: 2 (343), s. 5

2. Dz.U. $2003 \mathrm{nr} 80$ poz. 717, Ustawa z dnia 27 marca 2003 r. o planowaniu i zagospodarowaniu przestrzennym

3. Dz.U. $2007 \mathrm{nr} 127$, poz.880, Ustawa $\mathrm{z}$ dnia 11 maja 2007 r. o tworzeniu i działaniu wielkopowierzchniowych obiektów handlowych

4. Dz.U. 2015 poz. 1713, Ustawa z dnia 25 września 2015 r. o zmianie ustawy o planowaniu i zagospodarowaniu przestrzennym

5. Dz.U. 2016 poz. 1155, Ustawa z dnia 6 lipca 2016 r. o podatku od sprzedaży detalicznej

6. Dziesięć sieci zdominowało rynek handlowy w Polsce, www.wiadomoscihandlowe, dostęp 10.10.2016

7. Euromonitor International

8. Piotr Grauer, Michalina Kulig, Piotr Kuskowski, Mirosław Matusik, Na rozdrożu. Wyzwania i priorytety sieci spożywczych w Polsce, kpmg.pl

9. Grocery retail in Poland, PMR

10. Informacje prasowe, Handel w Polsce - prognozy na przyszłość, Warszawa, 22 maja 2014 r., http://www2.deloitte.com, data dostępu: 5.09.2016

11. Katalog Sieci Detalicznych w Polsce TRADE PRESS, http://sd.tradepress.com.pl/

12. Urszula Kłosiewicz-Górecka, Prezentacja raportu o handlu - stare i nowe dylematy rozwoju handlu w Polsce, Instytut Badań Rynku, Konsumpcji i Koniunktur , Polska Organizacja Handlu i Dystrybucji, konferencja z 18.01.2016

\footnotetext{
${ }^{16}$ Piotr Grauer, Michalina Kulig, Piotr Kuskowski, Mirosław Matusik, Na rozdrożu. Wyzwania i priorytety sieci spożywczych w Polsce, kpmg.pl
} 
13. Ministerstwo Finansów chce zawieszenia podatku handlowego do 2018 r.!, www.wiadomoscihandlowe.pl, data dostępu: 14.10.2016

14. Polska Izba Handlu PIH, Jak podatek od dyskontów i hipermarketów może wzmocnić właścicieli polskich sklepów?, 5.01.2016.

15. Unia Europejska zablokowała podatek od handlu, http://wgospodarce.pl/informacje/29467, data dostępu: 21.09 .2016

16. Jolanta Tkaczyk, Trendy konsumenckie i ich implikacje marketingowe, Handel wewnętrzny, Konsumpcja i konsument -nowe trendy, maj-czerwiec 2012, s.126-134

17. Artur Tomaszewski, Prezes Zarządu DNB Bank Polska, Co dalej z handlem w Polsce? Komentarze ekspertów, www.dnb.pl/pl/komentarze-ekspertow/art16,co-dalej-z-handlem-wpolsce.html , data dostępu: 3.09.2016

18. Joanna Wrzesińska, Rozwój wielkoobszarowych obiektów handlowych w Polsce [w] Zeszyty Naukowe SGGW w Warszawie, Ekonomika i Organizacja Gospodarki Żywnościowej, nr 72 (2008), str.161-170

19. Joanna Wrzesińska, Warunki rozwoju sklepów wielkopowierzchniowych w Polsce, Nowe trendy w dystrybucji produktów żywnościowych : determinanty i kierunki ewolucji / red. nauk. Zygmunt Waśkowski, Michał Sznajder, s. 34-45

\section{Summary}

The article attempts to identify factors contributing to the development of foreign retail chains on the Polish market, mainly in the food industry. Also, there are presented: information on mergers and acquisitions of retail chains, the structure of retail trade and its development prospects.

Changes in law regulations and the decisions of local authorities will have a significant impact on further development of the surveyed entities. Local authorities can affect the harmonious development of local trade networks by: preventing monopolization of the local market, ensuring the diversity of trade forms, effective distribution of shops and stimulating entrepreneurship and reducing local unemployment.

Key words: retail trade, food industry, retail chains.

\section{Informacje o autorze:}

dr inż. Joanna Wrzesińska-Kowal

Katedra Ekonomii i Polityki Gospodarczej

Wydział Nauk Ekonomicznych

ul. Nowoursynowska 166

02-787 Warszawa

tel.: (22) 59-340-34

e-mail: joanna_wrzesinska@sggw.pl 